\title{
Production of tilapia insulin-like growth factor-2 in high cell density cultures of recombinant Escherichia coli
}

\author{
Shao-Yang $\mathrm{Hu}^{\text {a }}$, Jen-Leih $\mathrm{Wu}^{\mathrm{b}}$, Jan-Hsiung Huang ${ }^{\mathrm{a}, *}$ \\ ${ }^{a}$ Laboratory of Fermentation, Graduate Institute of Agricultural Chemistry, National Taiwan University, Taipei 106, Taiwan, ROC \\ ${ }^{\mathrm{b}}$ Laboratory of Marine Biology and Biotechnology, Institute of Zoology, Academia Sinica, Nankang, Taipei 115, Taiwan, ROC
}

Received 16 July 2003; received in revised form 30 August 2003; accepted 12 September 2003

\begin{abstract}
An improved expression plasmid pET-insulin-like growth factor-2 (IGF2) was constructed and transferred into Escherichia coli BL21(DE3) for the expression of tilapia insulin-like growth factor-2. The recombinant insulin-like growth factor-2 was produced as inclusion bodies, and the recombinant insulin-like growth factor- 2 content was as high as $10.3 \%$ of the total protein content. For production of recombinant insulin-like growth factor-2 in E. coli, pH-stat fed-batch cultures were used to achieve a high cell density culture. A cell concentration $183 \mathrm{~g}^{-1}$ dry cell weight (DCW) was obtained after $30 \mathrm{~h}$ cultivation and plasmid stability was maintained at high levels. Expression of insulin-like growth factor-2 was induced at three different cell concentrations, 50, 78.5 , and $114.5 \mathrm{~g} \mathrm{l}^{-1}$ dry cell weight. When cells were induced at a cell concentration of $114.5 \mathrm{~g} \mathrm{l}^{-1} \mathrm{dry}$ cell weight, the amount of insulin-like growth factor-2 produced was $9.69 \mathrm{~g}^{-1}$ (11.3\% of the total protein). Using a simple purification process including inclusion body isolation, denaturation, refolding and Ni-NTA affinity chromatography, $19.51 \mathrm{mg}$ of insulin-like growth factor-2 was obtained from a $22.5 \mathrm{ml}$ of culture, and the recovery yield was $20.5 \%$. The biological activity of the purified IGF- 2 was demonstrated as promoting the growth of four different cell lines by the colorimetric bioassay and the best growth stimulation ratio was obtained for the Balb/3T3 clone $31 \mathrm{~A}$ cell line.
\end{abstract}

(c) 2003 Elsevier B.V. All rights reserved.

Keywords: Insulin-like growth factor-2; High-cell density; Fed-batch culture; Escherichia coli; Growth stimulation

\section{Introduction}

Insulin-like growth factor (IGF) is a single-chain polypeptide hormone with three disulfide bonds, which exists in variety of mammals and vertebrates including humans, cattle, chickens, and fish. During the past 20 years, IGF proteins have been character-

\footnotetext{
* Corresponding author. Tel.: +886-2-23630231x2481; fax: +886-2-23630573.

E-mail address: jhhuang@ntu.edu.tw (J.-H. Huang).
}

ized from species as diverse as humans, chickens, rats and sharks, with the majority of the information being obtained during the last decade through cDNA cloning (Jansen et al., 1983; Kajimoto and Rotwein, 1991; Shimatsu and Rotwein, 1987). Depending on the structure and function of the IGF, two types of IGFs, IGF-1 and IGF-2 has been classified (Baker et al., 1993; Cohick and Clemmons, 1993). In fish, in addition to a growth promotion function, IGF-1 can modulate calcium concentrations to balance changes in osmotic pressure (McCormick et al., 1991; 
Moriyama et al., 1993, 2000). However, while much is known about the function of insulin-like growth factor-1, less is known about IGF-2 as to whether it exhibits any roles distinct from those in IGF-1. Recently, tilapia IGF-2 cDNA was isolated from the liver and the protein sequence was expressed by GST fusion in Escherichia coli (Chen et al., 1997). Mature tilapia insulin-like growth factor-2 which consists of the $\mathrm{B}, \mathrm{C}, \mathrm{A}$, and $\mathrm{D}$ domains, is a small single-chain peptide of 70 amino acids. It can stimulate somatic growth and cell differentiation in vertebrates. Because of these biological activities, tilapia IGF-2 has attracted attention in the field of aquaculture and it is currently being developed as a fodder additive for growth promoter. Furthermore, for a detailed understanding of the function and role of IGF-2 in modulating physiology, a source of IGF-2 is necessary.

Although IGFs have been expressed in a variety of host systems, including yeast (Bayne et al., 1988; Gellerfors et al., 1989), bacteria, and mammalian cells (Ballotti et al., 1987), E. coli is still the most widely employed host for the production of IGFs because of ease of handling and high yield. In a number of publications (Kim and Lee, 1996; Yamada et al., 1996), IGF has been expressed as a fusion protein for availability of antibodies and ease of detection in E. coli. However, it is not an economical strategy from the production viewpoint because the separation steps required to release IGF protein have a high cost and this results in a low efficiency of recovery. For this reason, in this study, a new expression plasmid for tilapia IGF-2 was constructed by improving the plasmid pGEX2T-IGF2, which was designed to express IGF-2 as a fusion protein with glutathione-S-transferase (GST) as previously reported (Chen et al., 1997). In this new expression plasmid, IGF-2 has six histidines at the C-terminal for easy purification and consequently the yields are significantly improved. In our present investigation, we were concerned with high-level production of tilapia IGF-2 in fed-batch cultures of E. coli BL21(DE3). An effective fed-batch culture procedure was set up that achieved a high cell concentration of $183 \mathrm{gl}^{-1}$ dry cell weight $(\mathrm{DCW})$. In addition, the process of purification was also developed to obtain biologically active IGF-2. We expected that the results will be useful as a production model for other recombinant proteins expressed as inclusion bodies.

\section{Material and methods}

\subsection{Bacterial strains and plasmids}

Tilapia IGF-2 cDNA was cloned and the plasmid pGEX2T-IGF2 was constructed for expression in E. coli as described previously (Chen et al., 1997). For expression of the mature igf-2 gene, pET-IGF2 was constructed by cloning the igf-2 gene into pET28b as follows. The forward primer 5'-CCGACGCATCCATGGCGGAA ATGG was designed to contain an NcoI restriction site (underlined nucleotides). The reverse primer 5'-GACGACGCCCTCGAGTTCGGACTT was designed to contain an XhoI restriction site (underlined nucleotides). The complete coding region for the mature tilapia IGF-2 was amplified by PCR (GeneAmp PCR System 2400, The Perkin-Elmer Corporation, CA, USA) using the plasmid pGEX2T-IGF2 as the template. The PCR product was digested with $\mathrm{NcoI}$ and $\mathrm{XhoI}$ before it was cloned into the same enzyme site in the pET28b vector. The igf-2 gene was expressed under the strong $\mathrm{T} 7$ promoter by induction with isopropyl- $\beta$-D-thiogalactopyranoside (IPTG) (Sigma, St. Louis, MO, USA). E. coli DH5 $\alpha$ was used as a host strain for cloning and maintenance of the plasmids. E. coli BL21(DE3) was used as a host for expression of IGF-2.

\subsection{Growth medium and cultivation condition}

\subsubsection{Seed cultivation and shake flask cultivation}

E. coli BL21(DE3) cells which contained plasmid pET-IGF2 were stored in glycerol at $-30{ }^{\circ} \mathrm{C}$. Frozen glycerol cell stock $(500 \mu \mathrm{l})$ was inoculated into a $250 \mathrm{ml}$ flask containing $50 \mathrm{ml}$ Luria-Bertani (LB) medium (tryptone $10 \mathrm{gl}^{-1}$, yeast extract $5 \mathrm{gl}^{-1}, \mathrm{NaCl}$ $10 \mathrm{~g}^{-1}$ ) supplemented with $50 \mu \mathrm{g} \mathrm{ml}^{-1}$ of kanamycin in a shaking incubator at $37^{\circ} \mathrm{C}$ at $125 \mathrm{rpm}$. After $12 \mathrm{~h}$ cultivation, $1 \mathrm{ml}$ of culture was transferred to a $500 \mathrm{ml}$ Hinton flask containing $100 \mathrm{ml}$ LB medium supplemented with $50 \mu \mathrm{g} \mathrm{ml}^{-1}$ of kanamycin and incubated for $12 \mathrm{~h}$ under the same conditions as the seed culture. Shake flask experiments were carried out in SSP medium (yeast extract $10 \mathrm{gl}^{-1}$, glucose $5 \mathrm{gl}^{-1}$, $\mathrm{N}$-Z-Amine AS $15 \mathrm{gl}^{-1}, \mathrm{~K}_{2} \mathrm{HPO}_{4} 8 \mathrm{gl}^{-1}, \mathrm{KH}_{2} \mathrm{PO}_{4}$ $2 \mathrm{gl}^{-1}$; pH 7.5). A $500 \mathrm{ml}$ Hinton flask containing $100 \mathrm{ml} \mathrm{SSP}$ medium was inoculated with $2 \mathrm{ml}$ of seed culture and incubated at $37^{\circ} \mathrm{C}$ at $125 \mathrm{rpm}$. Following 
a $3 \mathrm{~h}$ cultivation ( $\left.\mathrm{OD}_{600} 1\right)$, IPTG was added to a final concentration of $0.06 \mathrm{mM}$ for expression of IGF-2. After $12 \mathrm{~h}$ cultivation, the cells were harvested for $16.5 \%$ Tricine SDS-PAGE and estimation of expression level.

\subsubsection{Fed-batch cultivation}

Fed-batch cultivation was carried out at $37^{\circ} \mathrm{C}$ in a 51 bioreactor (Biostat B., B. Braun Biotech International $\mathrm{GmbH}$, Melsungen, Germany) equipped with a built-in digital controller for $\mathrm{pH}$, temperature, agitation, dissolved oxygen and peristaltic pumps for acid, base, antifoam and nutrient. The pH (InPro 3030/325 combination pH electrode, Mettler-Toledo GmbH, Switzerland) and dissolved oxygen concentration (InPro 6000 series $\mathrm{O}_{2}$ sensors, Mettler-Toledo $\mathrm{GmbH}$, Switzerland) were controlled at the set points by on-line monitoring. The controller was interfaced with a computer through the Multi-Fermentor Control System software (Biostat B., B. Braun Biotech International $\mathrm{GmbH}$, Melsungen, Germany). The initial work volume was 1.301 of modified R-medium (Lee and Chang, 1993). The medium contained citric acid $3 \mathrm{gl}^{-1}, \mathrm{KH}_{2} \mathrm{PO}_{4}$ $6.75 \mathrm{~g} \mathrm{l}^{-1}, \quad\left(\mathrm{NH}_{4}\right)_{2} \mathrm{SO}_{4} \quad 5 \mathrm{gl}^{-1}, \quad \mathrm{Na}_{2} \mathrm{HPO}_{4} \cdot 12 \mathrm{H}_{2} \mathrm{O}$ $3 \mathrm{gl}^{-1}, \mathrm{MgCl}_{2} 1.5 \mathrm{gl}^{-1}, \mathrm{NH}_{4} \mathrm{Cl} 0.1 \mathrm{gl}^{-1}$, glucose $20 \mathrm{gl}^{-1}$, yeast extract $20 \mathrm{gl}^{-1}$, N-Z-Amine AS $30 \mathrm{gl}^{-1}$ and $6 \mathrm{mll}^{-1}$ of a trace metal solution. The composition of trace metal solution that contains (per $\mathrm{ml}$ of $5 \mathrm{M} \mathrm{HCl}$ ) $\mathrm{FeSO}_{4} \cdot 7 \mathrm{H}_{2} \mathrm{O} 10 \mathrm{mg}, \mathrm{ZnSO}_{4} \cdot 7 \mathrm{H}_{2} \mathrm{O}$ $2.25 \mathrm{mg}, \quad \mathrm{CaCl}_{2} \cdot 2 \mathrm{H}_{2} \mathrm{O} \quad 1.35 \mathrm{mg}, \quad \mathrm{MnSO}_{4} \cdot 5 \mathrm{H}_{2} \mathrm{O}$ $0.5 \mathrm{mg}, \mathrm{CuSO}_{4} \cdot 5 \mathrm{H}_{2} \mathrm{O} 1 \mathrm{mg}, \mathrm{AlCl} \cdot 6 \mathrm{H}_{2} \mathrm{O} 0.3 \mathrm{mg}$, $\left(\mathrm{NH}_{4}\right)_{6} \mathrm{Mo}_{7} \mathrm{O}_{24} \cdot 4 \mathrm{H}_{2} \mathrm{O} 0.1 \mathrm{mg}, \mathrm{H}_{3} \mathrm{BO}_{3} 0.2 \mathrm{mg}$, and thiamine- $\mathrm{HCl} 2 \mathrm{mg}$. Glucose was sterilized separately and trace metal solution was sterilized by filtration. The entire content of seed culture $(7.69 \% \mathrm{v} / \mathrm{v})$ was inoculated. The agitation speed and flow rate of aeration was set at $1000 \mathrm{rpm}$ and $31 \mathrm{~min}^{-1}$. The $\mathrm{pH}$ was kept at 7.0 by adding $28 \%(\mathrm{v} / \mathrm{v})$ ammonium water. The dissolved oxygen concentration was maintained above $20 \%$ of air saturation by increasing the percentage of pure oxygen using a gas mixer (Gas Mix Unit, B. Braun Biotech International $\mathrm{GmbH}$, Melsungen, Germany). A nutrient feeding solution was added by using the $\mathrm{pH}$-stat feeding strategy. The nutrient solution contained glucose $750 \mathrm{~g} \mathrm{l}^{-1}$, yeast extract $50 \mathrm{~g} \mathrm{l}^{-1}, \mathrm{~N}$ $\mathrm{Z}$-Amine AS $75 \mathrm{gl}^{-1}, \mathrm{MgSO}_{4} \cdot 7 \mathrm{H}_{2} \mathrm{O} 20 \mathrm{gl}^{-1}$, citric acid $3 \mathrm{gl}^{-1}, \mathrm{KH}_{2} \mathrm{PO}_{4} 6.75 \mathrm{gl}^{-1},\left(\mathrm{NH}_{4}\right)_{2} \mathrm{SO}_{4} 5 \mathrm{gl}^{-1}$, $\mathrm{Na}_{2} \mathrm{HPO}_{4} \cdot 12 \mathrm{H}_{2} \mathrm{O} 3 \mathrm{gl}^{-1}, \mathrm{MgCl}_{2} 5 \mathrm{gl}^{-1}, \mathrm{NH}_{4} \mathrm{Cl}$
$0.1 \mathrm{gl}^{-1}$. When the $\mathrm{pH}$ rose to a value greater than the set point ( $\mathrm{pH} 7.0$ ) by $0.1 \mathrm{U}$ due to the depletion of glucose, the nutrient feeding solution was automatically added to increase the glucose concentration in the culture broth. Expression of the igf-2 gene was induced by adding IPTG to a final concentration of $0.06 \mathrm{mM}$. Foam was suppressed as necessary by the addition of sterilized antifoam (Sigma A-5758).

\subsection{Purification of IGF-2 from the inclusion body}

Cells were harvested from $22.5 \mathrm{ml}$ of culture by centrifugation at $6000 \times g$ for $15 \mathrm{~min}$ at $4{ }^{\circ} \mathrm{C}$ and washed twice in PBS buffer $(140 \mathrm{mM} \mathrm{NaCl}, 2.7 \mathrm{mM} \mathrm{KCl}$, $10 \mathrm{mM} \mathrm{Na} 2 \mathrm{HPO}_{4} \cdot 12 \mathrm{H}_{2} \mathrm{O}, 1.8 \mathrm{mM} \mathrm{KH}_{2} \mathrm{PO}_{4} ; \mathrm{pH} 7.3$ ), then centrifuged again. The washed cell pellets were resuspended thoroughly in PBS buffer and disrupted by sonication using a sonicator (Model XL 2020, 419A microtipprobe, Misonix Inc., NY, USA) at a setting of 3 . The sonicator was programmed to provide $10 \mathrm{~s}$ pulses with $5 \mathrm{~s}$ pause for a total period of $30 \mathrm{~min}$. The disrupting pellets were washed with $50 \mathrm{ml}$ PBS buffer containing $3 \mathrm{M}$ urea to remove cell debris contaminants and were further centrifuged at $17,500 \times g$ for $30 \mathrm{~min}$ to isolate the inclusion bodies. The inclusion bodies were completely soluble in $50 \mathrm{ml}$ PBS buffer (pH 12) containing $5 \mathrm{M}$ urea at room temperature and the solubilized solution was clarified by centrifugation at $17,500 \times g$ for $30 \mathrm{~min}$ at $4{ }^{\circ} \mathrm{C}$. Refolding was initiated by diluting the solubilized protein in PBS buffer and the solution was then incubated at $4{ }^{\circ} \mathrm{C}$ for $36 \mathrm{~h}$. The refolded protein was centrifuged at $17,500 \times g$ for $30 \mathrm{~min}$ to remove any insoluble material. The supernatant fraction was collated and concentration by centrifugation using a type YM3 ultrafiltration membrane (molecular weight cutoff, 3000; Millipore, MA, USA) and then loaded to bind with the Ni-NTA gel (Qiagen). The gel was washed with $30 \mathrm{mM}$ imidazole and eluted with $250 \mathrm{mM}$ imidazole. The purified IGF-2 protein solution was dialyzed against PBS buffer and stored at $4{ }^{\circ} \mathrm{C}$ prepared for bioactivity assay.

\subsection{IGF-2 bioactivity assay}

The cell lines, growth medium and culture condition in this assay are shown in Table 1 . Four different cell lines, zebrafish liver cell (ZFL), tilapia 
Table 1

Cell lines, growth medium and culture condition used in IGF-2 bioactivity assay

\begin{tabular}{|c|c|c|c|c|}
\hline Cell line & Species and type & Growth medium ${ }^{\mathrm{a}, \mathrm{b}}$ & Culture condition & Reference and source \\
\hline ZFL & Zebrafish liver cell & L15 + fetal bovine serum & $28^{\circ} \mathrm{C}$ & Chen et al. (2001) \\
\hline TO-2 & Tilapia ovary cell & L15 + fetal bovine serum & $28^{\circ} \mathrm{C}$ & Chen et al. (1997) \\
\hline Balb/3T3 Clone 31A & Mouse embryol cell & DMEM $+10 \%$ calf serum & $37^{\circ} \mathrm{C}, 5 \% \mathrm{CO}_{2}$ & CCRC $60009^{c}$ \\
\hline MRC-5 & Human lung cell & $\mathrm{EM}+10 \%$ fetal bovine serum & $37^{\circ} \mathrm{C}, 5 \% \mathrm{CO}_{2}$ & CCRC $60023^{c}$ \\
\hline
\end{tabular}

${ }^{a}$ Growth medium used contained penicillin G sodium $100 \mathrm{Ul}^{-1}$, streptomycin sulfate $100 \mathrm{Ul}^{-1}$ and amphotercin $\mathrm{B} 25 \mu \mathrm{gl} \mathrm{l}^{-1}$.

$\mathrm{b}$ The medium and reagent were purchased from Gibco BRL.

c CCRC: Culture Collection and Research Center, Hsinchu, Taiwan.

ovary cell (TO-2), mouse embryo cell (Balb/3T3 clone 31A) and human lung cell (MRC-5), were used as the models for the bioactivity assay. The biological activity of IGF-2 was assayed by evaluating the ability to promote cell proliferation using the colorimetric bioassay method (Okajima et al., 1992). Cells were seeded at a density of $3 \times 10^{4}$ cells per well in 96-well microplates and cultured in growth medium under their optimal individual culture conditions. After $24 \mathrm{~h}$ incubation, the growth medium was discarded, and replaced with $100 \mu$ l of growth medium without serum and contained various concentrations of purified IGF-2. After $48 \mathrm{~h}$ cultivation, the cells were stained by adding $11 \mu \mathrm{l}$ of [3-(4,5-dimethyl-2-thiazolyl)-2,5-diphenyl-2H-tetrazolium bromide] (MTT) (Sigma M-5655) reagent to each well (final concentration was $0.5 \mathrm{mg} \mathrm{ml}^{-1}$ ) and incubated for $4 \mathrm{~h}$. Then $100 \mu \mathrm{l}$ of dimethyl sulfoxide (DMSO) (Sigma D-2650) was added to lyse the cells and the plates were then incubated for $1 \mathrm{~h}$ to extract the MTT-formazan product. Absorbances were read

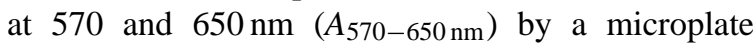
reader (Anthos 2020, Wals, Austria). Growth stimulation ratios were calculated using the following equation:

$$
\begin{aligned}
& \text { growth stimulation ratio (GSR) }(\% \text { control }) \\
& =\frac{A_{\text {sample }}}{A_{\text {control }}} \times 100
\end{aligned}
$$

where $A_{\text {control }}$ was the avarage absorbance of the wells which contained cells without added IGF-2 (control), $A_{\text {sample }}$ was the average absorbance of the wells which contained the cells stimulated with purified IGF-2 (sample).

\subsection{Analytical methods}

\subsubsection{Cell and protein concentration}

Approximately $7 \mathrm{ml}$ of culture sample was examined periodically. The cell concentration was measured using the optical density (OD) on a spectrophotometer (Hitachi U-2000, Tokyo, Japan) at $600 \mathrm{~nm}$ 0.3-0.6, either undiluted or after dilution. Dry cell weight was determined by centrifugation of $2 \mathrm{ml}$ culture in a pre-weighted microcentrifuge tube, followed by washing twice with distilled water and drying to a constant weight at $80^{\circ} \mathrm{C}$ in an oven. The protein concentration was determined by the Bradford protein assay method using bovine serum albumin as the standard (Bradford, 1976).

\subsubsection{Plasmid stability estimation}

A serial dilution of the culture broth sample was spread onto LB agar plates without antibiotic and incubated at $37^{\circ} \mathrm{C}$ for $12 \mathrm{~h}$. One hundred colonies were picked up and transferred to LB agar plate with kanamycin. Plasmid stability was determined by calculating the percentage of colonies resistant to kanamycin.

\subsubsection{Glucose and acetate assay}

The glucose concentration was determined at $570 \mathrm{~nm}$ using a microplate reader by the DNS method (Miller, 1959). Culture samples were prepared for acetic acid analysis by microcentrifuge at $12,000 \mathrm{rpm}$ for $5 \mathrm{~min}$. A $500 \mu \mathrm{l}$ sample of the supernatant culture broth was acidified by adding $10 \mu \mathrm{l}$ of $12 \mathrm{~N} \mathrm{HCl}$ and centrifuged again. A $200 \mu \mathrm{l}$ sample of the supernatant was mixed with an equal volume of $0.2 \%$ butyric acid solution that was used as the internal standard before acetic acid analysis. The quantity of 
the acetic acid was analyzed using gas chromatography (Hitachi G-3000, San Jose, CA, USA) with cp-wax $52 \mathrm{CB}$ column $(0.53 \mathrm{~mm} \times 30 \mathrm{~m}$, film thickness $1 \mu \mathrm{m}$, Corompak, Varian, Palo Alto, CA, USA). The conditions were as follows: carrier gas and flow rate, $\mathrm{H}_{2}$ and $3 \mathrm{ml} \mathrm{min}^{-1}$; inject temperature, $240^{\circ} \mathrm{C}$; detector and detector temperature, FID and $260^{\circ} \mathrm{C}$; oven program, $120^{\circ} \mathrm{C}$ held for $5 \mathrm{~min}$ and than raised the temperature $10^{\circ} \mathrm{Cmin}^{-1}$ until the temperature reached $200^{\circ} \mathrm{C}$ and then held for another $5 \mathrm{~min}$.

\subsubsection{IGF-2 purity analysis}

The IGF-2 content, separated by electrophoresis, was quantified using a densitometer (ID Image Analysis Software, Kodak Digital Science, NY, USA). The purity of purified IGF-2 was analyzed by HPLC equipped with a betabasic- 8 column ( $4.6 \mathrm{~mm} \times 150 \mathrm{~mm}, 5 \mu \mathrm{m}$, Keystone Scientific Inc., Bellefonte, PA, USA). Elution was performed using $25 \%$ acetonitrile containing $0.1 \%$ trifluoroacetic acid at a flow rate of $0.5 \mathrm{ml} \mathrm{min}^{-1}$.

\subsubsection{Determination of $N$-terminal amino acid sequence and mass spectrum}

Protein samples were analyzed using $16.5 \%$ Tricine SDS-PAGE gel (Schagger and Jagow, 1987) and stained with Coomassie brilliant blue R-250 (Bio-Rad). Electroblotting of purified IGF-2 to polyvinylidene difluoride (PVDF) immobilon membrane (Millpore, Bedford, MA, USA) was performed according to the method of Matsudaira (1987). The $\mathrm{N}$-terminal sequence of IGF-2 was determined by Edman degradation using a model 476A sequencer (Applied Biosystems). The molecular mass of purified IGF-2 was determined by mass spectrometry (Quattro Ultima, Micromass, UT, USA).

\section{Results}

\subsection{Expression and characterization of the tilapia IGF-2 gene in E. coli}

The expression plasmid pET-IGF2 encoding the tilapia IGF-2 are derived from pET28b and used to transform E. coli BL21(DE3) for expression (Fig. 1). The amino acid, Alanine, which generated from restriction site, exists between the start codon ATG (Met)
(A)
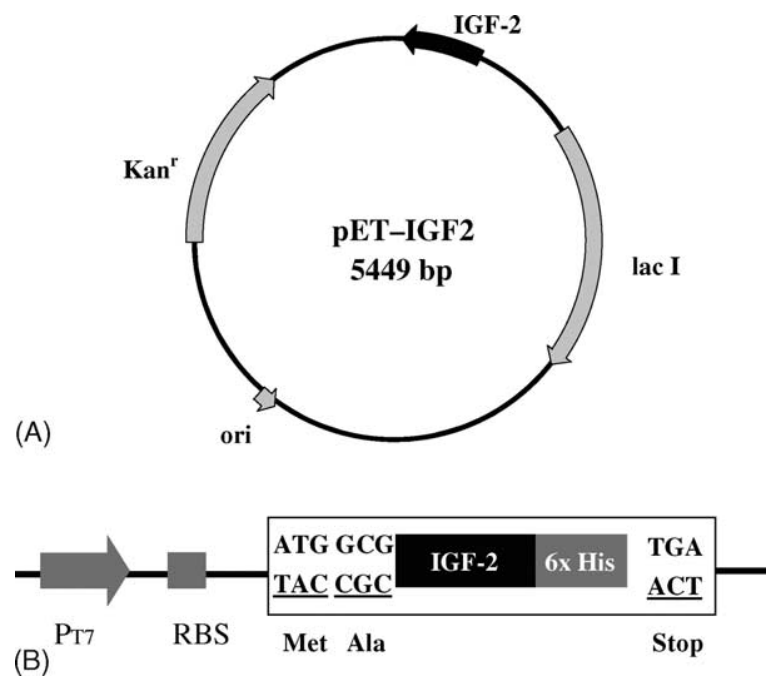

Fig. 1. Construction of the recombinant expression plasmid pET-IGF2. (A) The PCR fragment (length, $224 \mathrm{bp}$ ) which encodes mature tilapia IGF-2 was digested with $\mathrm{NcoI}$ and $\mathrm{XhoI}$ and then cloned into pET28b at the same restriction sites. $\operatorname{Kan}^{\mathrm{r}}$, kanamycin resistance; lacI, lac repressor; ori, the origin gene of replication. (B) Diagram illustrating the main features of pET-IGF2. Expression of the tilapia igf-2 gene is controlled by T7 promoter (PT7). RBS, ribosome binding site.

and the mature IGF-2. The C-terminal of mature IGF-2 was tagged with six histidines for purification using Ni-NTA affinity chromatography. Cells were grown in SSP medium and induced with $0.06 \mathrm{mM}$ IPTG at an $\mathrm{OD}_{600}$ of 1 . More than $90 \%$ of the recombinant IGF-2 was expressed as inclusion bodies even when the culture temperature was down shifted to $27^{\circ} \mathrm{C}$. The IGF-2 content level was about $10.3 \%$ of the total protein (Fig. 2).

\subsection{High cell density culture of recombinant E. coli}

Fed-batch cultivations using a pH-stat strategy were carried out in order to achieve high cell densities of the recombinant $E$. coli strain. When the initial glucose $\left(20 \mathrm{gl}^{-1}\right)$ in the bioreactor was exhausted at a cultivation time of $6 \mathrm{~h}$, the addition of feeding solution was started due to the $\mathrm{pH}$ rising over the set value of 7.1. With glucose being the limiting parameter during the batch phase, a specific growth rate $(\mu)$ of $0.65 \mathrm{~h}^{-1}$ and a yield coefficient for glucose of $0.453 \mathrm{~g} \mathrm{~g}^{-1}$ was attained. The glucose concentration was kept under $1.5 \mathrm{~g}^{-1}$ during the fed-batch culture 


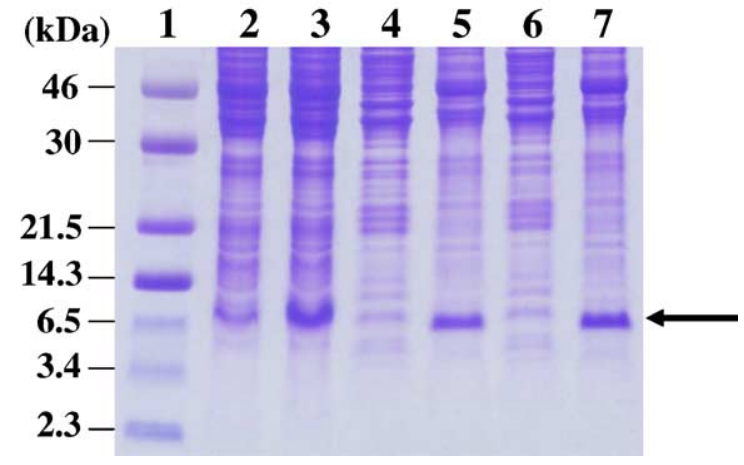

Fig. 2. Expression of tilapia IGF-2 mature peptide in E. coli BL21(DE3) by a flask culture. (A) The proteins were analyzed by $16.5 \%$ Tricine SDS-PAGE. Lane: 1 , molecular mass standard; 2 , the total protein without IPTG induction at $37^{\circ} \mathrm{C} ; 3$, the total protein with IPTG induction at $37^{\circ} \mathrm{C} ; 4$, soluble protein with IPTG induction at $37^{\circ} \mathrm{C} ; 5$, insoluble protein with IPTG induction at $37^{\circ} \mathrm{C} ; 6$, soluble protein with IPTG induction at $27^{\circ} \mathrm{C} ; 7$, insoluble protein with IPTG induction at $27^{\circ} \mathrm{C}$.

to avoid accumulation of acetic acid. Hence, during the process of cultivation, acetate concentration was maintained below $1 \mathrm{gl}^{-1}$. In the fed-batch phase, the specific growth rate $(\mu)$ descends to $0.057 \mathrm{~h}^{-1}$ due to nutrient limitation by glucose $\left(<1.5 \mathrm{~g}^{-1}\right)$ and the yield coefficient for glucose was maintained about $0.427 \mathrm{~g} \mathrm{~g}^{-1}$. Pure oxygen was supplied to accommodate the increasing rate of oxygen consumption accompanying cell growth. By this mean, the dissolved oxygen concentration could be maintained above $20 \%$ of air saturation during the culture. By keeping excellent growth conditions for cell growth in the bioreactor, a high density of biomass of $183 \mathrm{~g} \mathrm{l}^{-1}$ DCW was achieved after $30 \mathrm{~h}$ cultivation and $91 \%$ of the cells still contained the expression plasmid (Fig. 3).

\subsection{Expression of tilapia IGF-2 at varying cell densities}

In order to evaluate the efficiency of expression at the time of induction, cells were induced with $0.06 \mathrm{mM}$ IPTG at three different cell concentrations (50, 78.5 and $\left.114.5 \mathrm{gl}^{-1} \mathrm{DCW}\right)$. Fig. 4 shows the time profile for cell density $\left(\mathrm{OD}_{600}\right)$, dry cell weight, and IGF-2 content expressed as a percentage of the total protein content. When cells were induced at the low cell concentration $\left(50 \mathrm{gl}^{-1} \mathrm{DCW}\right)$, the fraction of IGF-2 in the total protein increased for $15 \mathrm{~h}$ after induction and then decreased slightly (Fig. 4A). The dry cell weight and the maximal IGF- 2 content were $94.5 \mathrm{~g} \mathrm{l}^{-1}$ and $15.27 \%$ of total protein, respectively. When cells were induced at the intermediate cell density (78.5 $\left.\mathrm{g}^{-1} \mathrm{DCW}\right)$, the fraction of IGF-2 increased for $18 \mathrm{~h}$ after induction and than decreased. The cell dry weight and the maximal IGF- 2 content were $125.78 \mathrm{gl}^{-1}$ and $12.11 \%$ of total protein, respectively (Fig. 4B). When cells were induced at the high cell concentration (114.5 $\left.\mathrm{g}^{-1} \mathrm{DCW}\right)$, the IGF-2

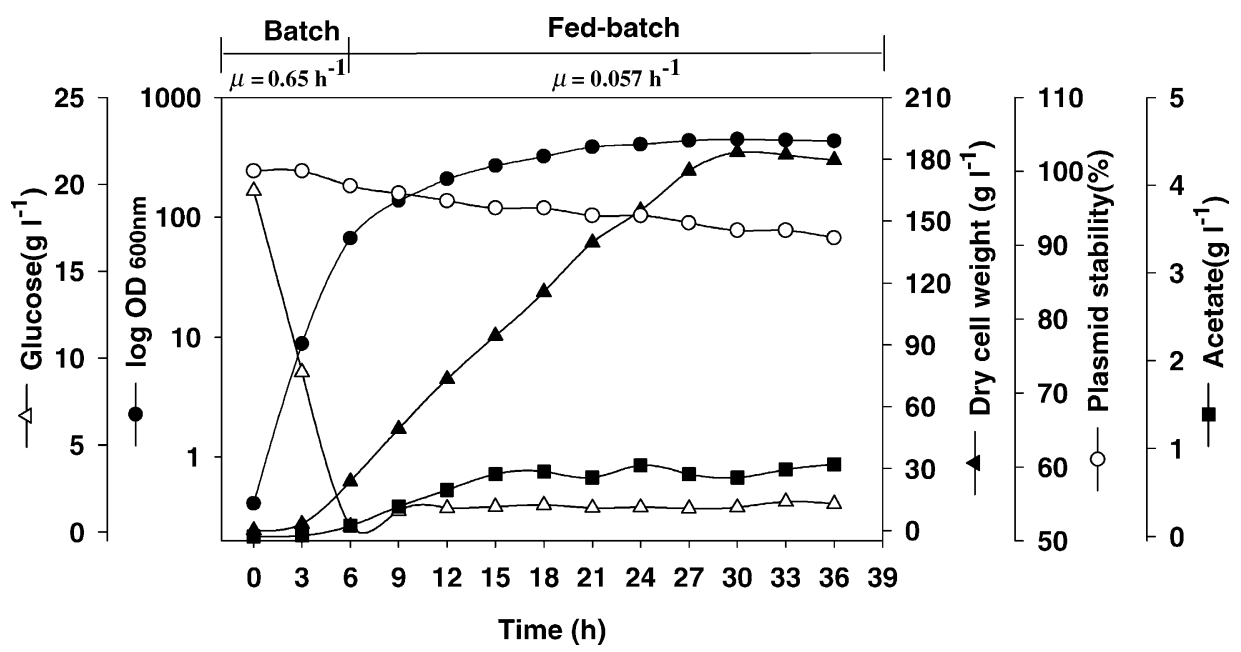

Fig. 3. High cell density fed-batch cultivation of recombinant Escherichia coli BL21(DE3). Log OD $_{600}(\mathbf{O})$, dry cell weight ( $\left.\mathbf{\Delta}\right)$, plasmid stability $(\bigcirc)$, glucose $(\triangle)$, acetic acid $(\square)$. Fed-batch culture started at $6 \mathrm{~h}$ after unlimited growth in the batch phase. 


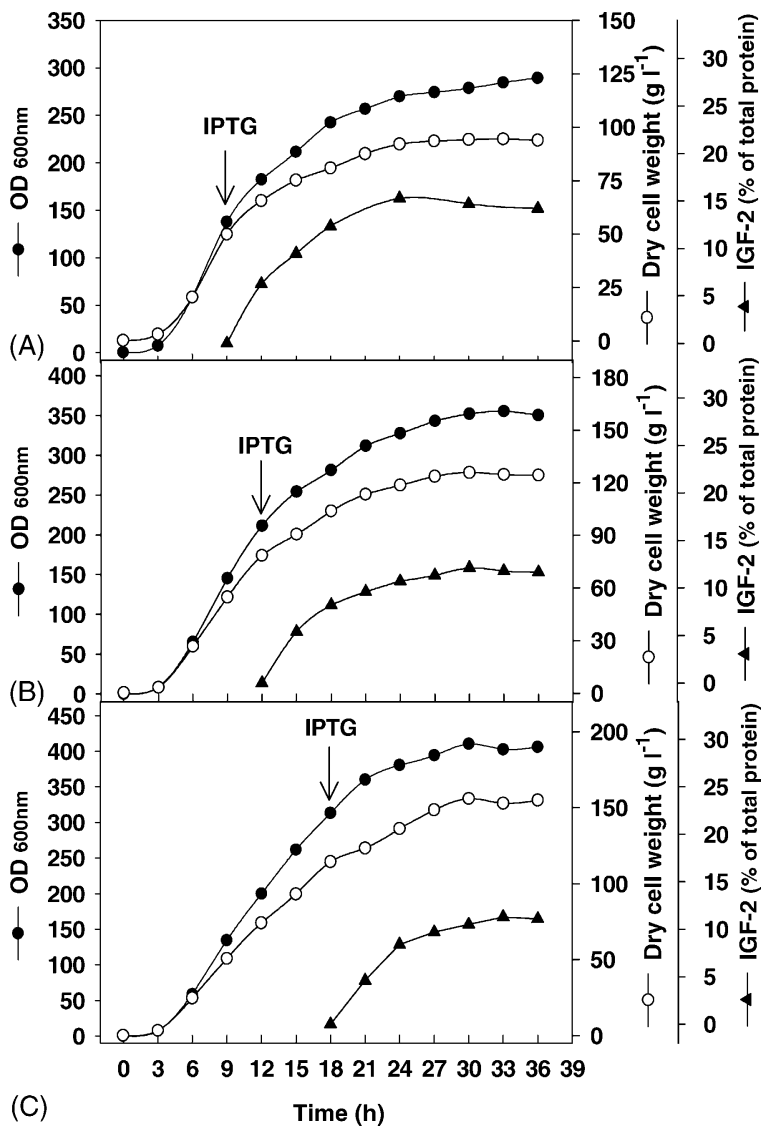

Fig. 4. Time profiles for cell density $\left(\mathrm{OD}_{600}\right)(\mathbf{)})$, cell dry weight $(\mathrm{O})$, and IGF-2 content $(\boldsymbol{\Delta})$ during fed-batch cultivation with induction at the low cell concentration (A), the intermediate cell concentration (B), and the high cell concentration (C). The arrow indicated the time of induction. content increased continually for $18 \mathrm{~h}$. The maximal dry cell weight and maximal IGF-2 content were $156 \mathrm{~g}^{-1}$ and $11.3 \%$ of the total protein, respectively (Fig. 4C). In the main, no large variation happened in the IGF-2 content when IPTG was induced at different cell concentration. Therefore, the largest amount of IGF-2 was produced when cells were induced at the high cell concentration $\left(114.5 \mathrm{~g} \mathrm{l}^{-1}\right.$ DCW), and the concentration of IGF-2 was as high as $9.69 \mathrm{gl}^{-1}$.

\subsection{Purification of recombinant IGF-2}

Recombinant IGF-2 was purified from $22.5 \mathrm{ml}$ of culture from a fed-batch culture induced at the high cell concentration as described above. The results are summarized in Table 2. The final amount of the IGF-2 and recovery yield was $19.512 \mathrm{mg}$ and $20.54 \%$, respectively. The purity of IGF-2 as determined by $16.5 \%$ Tricine SDS-PAGE to be greater than $91 \%$ and the purity of the IGF-2 as determined by HPLC was $90 \%$ (Fig. 5). This results of purification indicated that $869.67 \mathrm{mg} \mathrm{l}^{-1}$ of purified IGF-2 was obtained from the fed-batch culture. A mass spectrum analysis of the purify IGF-2 was $9072.8 \mathrm{Da}$, which is consistent with the molecular mass of the tilapia IGF-2 plus the amino acid generated by the restriction site and plus the six of histidines.

\subsection{Characterization and bioactivity of $I G F-2$}

For characterization of the purified IGF-2 protein, N-terminal amino acid sequencing was analyzed. The amino acid sequence following Ala was Glu-Met-Ala-Ser-Ala-Glu, which was identical to that of the native IGF-2. The biological activity of the

Table 2

Protein recovery in a representative experiment: extraction from inclusion bodies ${ }^{\mathrm{a}}$

\begin{tabular}{lclllcc}
\hline Purification step & Volume $(\mathrm{ml})$ & $\begin{array}{l}\text { Concentration } \\
\text { of protein } \\
\left(\mathrm{mg} \mathrm{ml}^{-1}\right)^{\mathrm{b}}\end{array}$ & $\begin{array}{l}\text { Amount of } \\
\text { total protein } \\
(\mathrm{mg})\end{array}$ & $\begin{array}{l}\text { Amount of } \\
\text { IGF-2 }(\mathrm{mg})\end{array}$ & $\begin{array}{l}\text { IGF-2 } \\
\text { recovery }(\%)\end{array}$ \\
\hline Solubilized inclusion body & 50 & 5.88 & 294 & 94.962 & $\begin{array}{l}\text { Purity } \\
(\%)\end{array}$ \\
Dilution and refolding & 1000 & 0.183 & 183.2 & 65.05 & 68.50 & $32.3^{\mathrm{c}}$ \\
Ni-NAT affinity chromatography & 40 & 0.542 & 21.68 & 19.512 & $35.51^{\mathrm{c}}$ \\
\hline
\end{tabular}

a A $22.5 \mathrm{ml}$ fed-batch culture was induced at the high cell concentration of $114.5 \mathrm{~g} \mathrm{l}^{-1} \mathrm{DCW}$.

b Concentration of total protein was determined with the Bradford method.

c Determined by densitometric scanning of Tricine SDS-PAGE gels.

${ }^{\mathrm{d}}$ Determined by HPLC. 


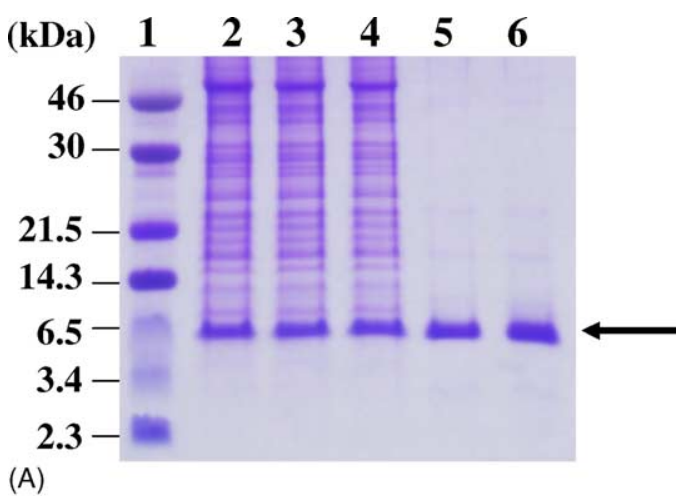

(A)

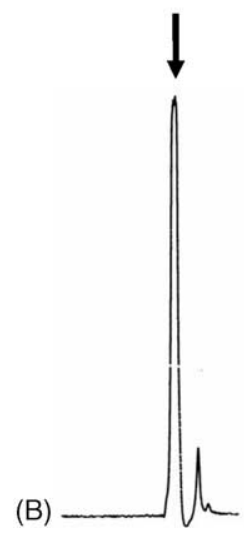

Fig. 5. Samples from each purification step analyzed by $16.5 \%$ Tricine SDS-PAGE gel. (A) Lane 1, molecular mass standards; 2, inclusion body fraction after washing with $3 \mathrm{M}$ urea; 3 , supernatant after $5 \mathrm{M}$ urea and $\mathrm{pH} 12$ denaturation and centrifugation; 4, supernatant after refolding and centrifugation; 5 and 6 , sample after Ni-NTA affinity chromatography and dialysis. (B) Reverse phase HPLC analysis of purified IGF-2. Arrow indicated the peak of purified IGF-2.

purified IGF-2 was further confirmed. MTT method as described in Section 2 was used to determine the effect of purified IGF-2 with different concentration on promoting proliferation of the cell lines. Compared with the growth of the cells without the addition of IGF-2, an effective growth-promoting action in the presence of different concentrations of IGF-2 from 5 to $120 \mathrm{nM}$ was observed. Furthermore, the IGF-2 gave different growth stimulation responses on different cell lines (Fig. 6). The growth stimulation ratios on the four different cell lines at IGF-2 concentration from 30 to $120 \mathrm{nM}$ were significantly different $(P<0.05)$. The greatest increase in growth-promotion was with the Balb/3T3 clone $31 \mathrm{~A}$ cell line and a growth stimu-

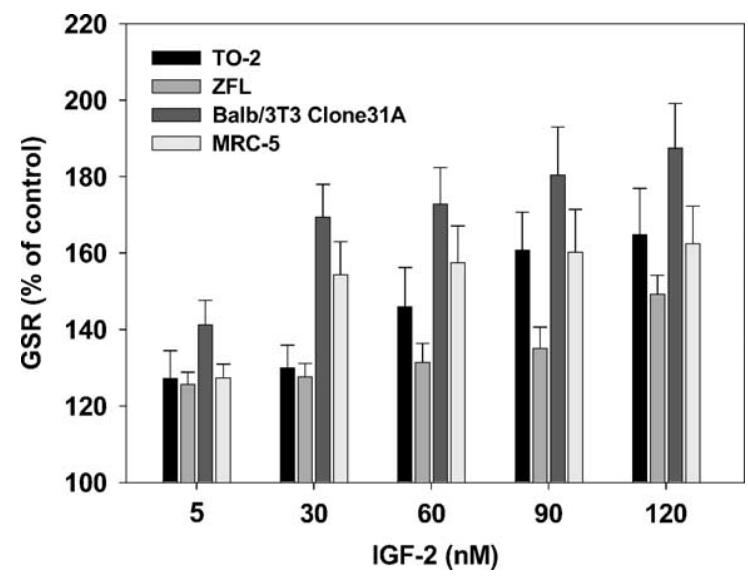

Fig. 6. The bioassay of recombinant tilapia IGF-2. The bioactivity of IGF-2 was measured with MTT method as described in Section 2. The growth stimulation ratios (GSR) were evaluated after $48 \mathrm{~h}$ cultivation and the results were compared with cells in the absence of IGF-2 treatment. Growth stimulation ratios are shown as means \pm S.D. $(n=6)$. The growth stimulation ratios on the four different cell lines at IGF-2 concentration from 30 to $120 \mathrm{nM}$ were significantly different $(P<0.05)$.

lation ratio of $187 \%$ was obtained in the presence of $120 \mathrm{nM}$ of IGF-2.

\section{Discussion}

IGF-2 has previously been purified from E. coli using the GST fusion system; however, low recovery yields were obtained during the separation and purification process for this fusion protein. In addition, the separation of the fusion into its two components by thrombin increased the cost of the production significantly. Because of these problems, a new expression plasmid for IGF-2 production was constructed. The igf-2 gene on pET-IGF2 encodes a recombinant tilapia IGF-2 tagged with an extension of six histidyl residues $(6 \times$ His $)$ at the carboxyl terminus. This tag can be used for purification by Ni-NTA affinity chromatography. In order to improve productivity and obtain a large amount of IGF-2, a high cell density culture technique with $\mathrm{pH}$-stat strategy was used in this study. The nutrient feeding strategy is based on the finding that $\mathrm{pH}$ increases when the carbon source is depleted. Therefore, glucose was controlled at low concentration (below $1.5 \mathrm{~g}^{-1}$ ) to avoid the 
accumulation of acetic acid during the fed-batch stage. It is well-known that acetate is overproduced when E. coli is grown under anaerobic or oxygen-limiting conditions (Luli and Strohl, 1990). Thus, pure oxygen was supplied to maintain the dissolved oxygen above $20 \%$ of air saturation and the acetic acid concentration could be maintained effectively below $1 \mathrm{gl}^{-1}$ during the process of cultivation. This acetate concentration was lower than the $5 \mathrm{~g} \mathrm{l}^{-1}$ that causes a lower growth rate, a lower biomass yield, and a lower maximum attainable cell density in high cell density culture (Lee, 1996). Therefore, a high density of biomass $183 \mathrm{~g}^{-1} \mathrm{DCW}$ was achieved after $30 \mathrm{~h}$ cultivation by maintaining these optimal growth conditions.

In this study, the final biomass concentration $\left(183 \mathrm{~g} \mathrm{l}^{-1} \mathrm{DCW}\right)$ approaches to the maximum theoretical cell mass concentration (160-200 $\mathrm{g} \mathrm{l}^{-1} \mathrm{DCW}$ ) as described in Märkl et al. (1993). Only two other publications describe high cell densities close to this. These are $190 \mathrm{gl}^{-1} \mathrm{DCW}$ for E. coli $\mathrm{K}-12$ in dialysis bioreactor (Nakano et al., 1997), and $204.3 \mathrm{gl}^{-1}$ DCW for a recombinant $E$. coli producing poly(3-hydroxybutyrate) (PHB) (Wang and Lee, 1997). When these two cases are compared with this study, the dialysis system was an expensive approach and not easy to scale up to a factory process. The product of the other case, PHB, is a high-molecular weight polymer that cause no osmotic stress on the cell and does not adversely affect overall bacterial growth. Because most of the research in case of PHB was aimed at maximizing the PHB content, the real cell mass (real cell mass $=$ total biomass - PHB) was generally below $30-40 \mathrm{~g}^{-1}$ DCW (Srinivasan et al., 2002). In our study, a $183 \mathrm{~g}^{-1} \mathrm{DCW}$ of cell concentration was almost the maximum cell concentration that could be obtained without any changes to the bioreactor system.

The efficiency of IGF-2 expression was estimated by IPTG induction at different cell concentrations; however, this resulted in little change to the IGF-2 content. Furthermore, cell growth was manifested as a deceased cell growth rate regardless of when the induction was performed. This phenomenon resulted from the expression of recombinant IGF-2, which caused a metabolic burden on growth as mentioned by Glick (1995). Therefore, when IPTG was induced at early stage of growth, cell growth was restricted strictly by metabolic stress and a lower biomass was obtained. For this reason, the largest amount of IGF-2 was obtained at higher cell concentration through induction during the late growth phase and this improved the productivity of IGF-2. When cells were induced at a high cell density of $114.5 \mathrm{~g} \mathrm{l}^{-1} \mathrm{DCW}$, the maximum cell mass and amount of IGF-2 produced was $156 \mathrm{gl}^{-1}$ DCW and $9.69 \mathrm{gl}^{-1}$ (11.3\% of total protein), respectively, and the specific IGF-2 productivity was highest $\left(2.07 \mathrm{mg} \mathrm{g}^{-1} \mathrm{DCW} \mathrm{h}^{-1}\right)$.

Due to the complicated structure of IGFs (three disulfide binds), the recombinant IGFs is usually expressed as inclusion bodies in E. coli. However, production of a recombinant protein from inclusion bodies has several advantages, such as resistance to proteolytic degradation and simple primary recovery from the total protein. Therefore, biological active IGFs from different species have been produced from inclusion bodies in a number of studies (Fine et al., 1997; Upton et al., 1995; Wangsa-Wirawan et al., 1997). In our study, $19.512 \mathrm{mg}$ of biologically active IGF-2 that was more than $90 \%$ pure was obtained from a $22.5 \mathrm{ml}$ culture after a series of simple recovery steps (recovery yield, $20.54 \%$ ). In the case of fed-batch cultivation with induction at the high cell concentration, a total of $33.9 \mathrm{~g}$ of IGF-2 was produced from 3.51 of culture broth (final volume of the culture), and $3.04 \mathrm{~g}$ of biologically active IGF- 2 was obtained after purification.

The recombinant IGF-2 showed efficient growthpromoting activity in a variety of cell lines, including ZFL, TO-2, Balb/3T3 clone31A and MRC-5 and this indicates that the process of purification is effective. According to Chen et al. (1997), recombinant tilapia IGF-2 is biologically active on the TO-2 cell line at concentrations between 15 and $120 \mathrm{nM}$ using a $\left[{ }^{3} \mathrm{H}\right]$ thymidine incorporation assay. In our study, the produced IGF-2 was biologically active and functioned in this range of concentrations, and it gave different growth stimulation ratios on the different cell lines. Presumably the membranes of the four cell lines have different IGF receptors with different binding affinities for IGF-2. Because the amino acid sequence of the tilapia and mammalian IGF-2 mature peptide is quite conserved (above $80 \%$ similarity), the recombinant tilapia IGF-2 is also functional for the Balb/3T3 clone31A and MRC-5 cell lines. As mention by DeChiara et al. (1990), IGF-2 plays an important role in the development of the embryo as a regulatory factor in embryo growth; therefore it is also called a fetal 
growth factor. This explains why the highest growth stimulation ratio was for the Balb/3T3 clone31A cell line. Given the above results, we suggest that it should be possible to develop the recombinant tilapia IGF-2 as growth promoters in livestock industry or as a medical reagent.

In this report, we have described an improved expression plasmid for IGF-2, an efficient production system for large quantities of recombinant tilapia IGF-2 by fed-batch cultivation and a simple process for the purification and refolding of IGF-2 into a biologically active form. The strategies described may be useful for the efficient production of other recombinant proteins expressed as inclusion bodies in E. coli.

\section{Acknowledgements}

This work was supported by grants from the National Science Council NSC89-2317-B-002-006, NSC90-2317-B-002-002, NSC91-2317-B-002-009 and Mithra Bioindustry Co. Ltd.

\section{References}

Baker, J., Liu, J.P., Robertson, E.J., Efstratiadis, A., 1993. Role of insulin-like growth factors in embryonic and postnatal growth. Cell 75, 73-82.

Ballotti, R., Nielsen, F.C., Pringle, N., Kowalski, A., Richardson, W.D., Van Obbereghhen, E., Gammeltoft, S., 1987. Insulin-like growth factor-1 in cultured rat astrocytes: expression of the gene, and receptor tyrosine kinase. EMBO J. 6, 3633-3639.

Bayne, M.L., Applebaum, J., Chicci, G.C., Hayes, N.S., Green, B.G., Cascieri, A., 1988. Expression, purification and characterization of recombinant human insulin-like growth factor-1 in yeast. Gene 66, 235-244.

Bradford, M.M., 1976. A rapid and sensitive method for the quantitation of microgram quantities of protein utilizing the principle of protein-dye binding. Anal. Biochem. 72, 248-254.

Chen, J.Y., Chang, C.Y., Chen, J.C., Shen, S.C., Wu, J.L., 1997. Production of biologically active recombinant tilapia insulin-like growth factor-2 polypeptides in Escherichia coli cells and characterization of the genomic structure of the coding region. DNA Cell Biol. 16, 883-892.

Chen, H.C., Lin, G.H., Gong, H.Y., Weng, C.F., Chang, C.Y., Wu, J.L., 2001. The characterization of prepro-insulin-like growth factor-1 Ea-2 expression and insulin-like growth factor-1 gene (devoid $81 \mathrm{bp}$ ) in the zebrafish (Danio rerio). Gene 268, 67-75.

Cohick, W.S., Clemmons, P.R., 1993. The insulin-like growth factors. Annu. Rev. Physiol. 55, 131-153.
DeChiara, T.M., Efstratiadis, A., Robertson, E.J., 1990. A growth deficiency phenotype in heterozygous mice carrying an insulinlike growth factor- 2 gene disrupted by targeting. Nature 345 , 78-80.

Fine, M., Amuly, R., Sandowski, Y., Marchant, T.A., Chan, S.J., Gertler, A., Funkenstein, B., 1997. Recombinant gilthead seabream (Sparus aurata) insulin-like growth factor-1: subcloning, expression in Escherichia coli, purification and characterization. J. Endocrinol. 153, 139-150.

Gellerfors, P., Axelsson, K., Helander, A., Johansson, S., Kenne, L., Lindqvist, S., Pavlu, B., Skottner, A., Fryklund, L., 1989. Isolation and characterization of a glycosylated form of human insulin-like growth factor-1 produced in Saccharomyces cerevisiae. J. Biol. Chem. 264, 235-244.

Glick, B.R., 1995. Metabolic load and heterologous gene expression. Biotechnol. Adv. 13, 247-261.

Jansen, M., Van Schaik, F.M.A., Ricker, A.T., Bullock, B., Woods, D.E., Gabbay, K.H., Nussbaum, A.L., Sussenbach, J.S., Van Den Brande, J.L., 1983. Sequence of cDNA encoding human insulin-like growth factor-1 precursor. Nature 306, 609-611.

Kajimoto, Y., Rotwein, P., 1991. Structure of the chicken insulin-like growth factor-1 gene reveals conserved promoter. J. Biol. Chem. 266, 9724-9731.

Kim, S.O., Lee, Y.I., 1996. High-level expression and simple purification of recombinant human insulin-like growth factor-1. J. Biotechnol. 18, 97-105.

Lee, S.Y., 1996. High cell-density culture of Escherichia coli. Trends Biotechnol. 14, 98-105.

Lee, S.Y., Chang, N.H., 1993. High cell density cultivation of Escherichia coli W using sucrose as a carbon source. Biotechnol. Lett. 15, 971-974.

Luli, G.W., Strohl, W.R., 1990. Comparison of growth, acetate production, and acetate inhibition of Escherichia coli strains in batch and fed-batch fermentations. Appl. Environ. Microbiol. 56, 1004-1011.

Märkl, H., Zenneck, C., Dubach, A.C., Ogbonna, J.C., 1993. Cultivation of Escherichia coli to high cell densities in a dialysis reactor. Appl. Microbiol. Biotechnol. 39, 48-52.

Matsudaira, P., 1987. Sequence from picomole quantities of proteins electroblotted onto polyvinylidene difluoride membranes. J. Biol. Chem. 262, 10035-10038.

McCormick, S.D., Sakamoto, T., Hasegawa, S., Hirano, T., 1991. Osmoregulatory actions of insulin-like growth factor-1 in rainbow trout (Oncorhynchus mylciss). J. Endocrinol. 130, 8792.

Miller, G.L., 1959. Use of dinitrosalicylic acid reagent for determination of reducing sugar. Anal. Chem. 31, 426-428.

Moriyama, S., Duguay, S.J., Conlon, J.M., Duan, C., Dickhoff, W.W., Plisetskaya, E.M., 1993. Recombinant coho salmon insulin-like growth factor-1: expression in Escherichia coli, purification and characterization. Eur. J. Biochem. 218, 205211.

Moriyama, S., Ayson, F.G., Kawauchi, H., 2000. Review: growth regulation by insulin-like growth factor-1 in fish. Biosci. Biotechnol. Biochem. 64, 1553-1562.

Nakano, K., Rischke, M., Sato, S., Märkl, H., 1997. Influence of acetic acid on the growth of Escherichia coli K-12 
during high-cell density in dialysis reactor. Appl. Microbiol. Biotechnol. 48, 597-601.

Okajima, T., Nakamura, K., Zhang, H., Ling, N., Tanabe, T., Yasuda, T., Rosenfeld, R.G., 1992. Sensitive colorimetric bioassays for insulin-like growth factor (IGF) stimulation of cell proliferation and glucose consumption: use in studies of IGF analogs. Endocrinology 130, 2201-2212.

Schagger, H., Jagow, G.V., 1987. Tricine-sodium dodecyl sulfate polyacrylamide gel electrophoresis for the separation of protein in the range from 1 to $100 \mathrm{kDa}$. Anal. Biochem. 166, 368-379.

Shimatsu, A., Rotwein, P., 1987. Mosaic evolution of the insulinlike growth factors: organization, sequence, and expression of the rat insulin-like growth factor-1 gene. J. Biol. Chem. 262, 7894-7900.

Srinivasan, S., Barnard, G.C., Gerngross, T.U., 2002. A novel high-cell-density protein expression system based on Ralstonia eutropha. Appl. Environ. Microbiol. 68, 5925-5932.
Upton, Z., Francis, G.L., Kita, K., Wallace, J.C., Ballard, F.J., 1995. Production and characterization of recombinant chicken insulin-like growth factor-2 from Escherichia coli. J. Mol. Endocrinol. 14, 90-94.

Wang, F., Lee, S.Y., 1997. Production of poly(3-hydroxybutyrate) by fed-batch culture of filamentation-suppressed recombinant Escherichia coli. Appl. Environ. Microbiol. 34, 382385.

Wangsa-Wirawan, N.D., Lee, Y.S., Falconer, R.J., Mansell, C.J., O'Neill, B.K., Middelberg, A.P.J., 1997. Novel fed-batch strategy for the production of insulin-like growth factor-1 (IGF-1). Biotechnol. Lett. 19, 1079-1082.

Yamada, H., Saito, Y., Fujimoto, T., Noguchi, Y., Mori, T., Miura, T., Kobayashi, M., Shimomura, K., 1996. Large scale purification of recombinant insulin-like growth factor-1 (IGF-1, Mecasermin) from a fused-protein produced in Escherichia coli. J. Ferment. Bioeng. 82, 134-139. 